\title{
Pengaruh Efektivitas Iklan Burgushi Melalui Instagram Ads terhadap Minat Beli Generasi Milenial
}

\author{
Sugiarto Alwen Lestiono ${ }^{1}$, Diah Ayu Chandraningrum ${ }^{2 *}$ \\ 'Fakultas Ilmu Komunikasi, Universitas Tarumanagara, Jakarta \\ Email: alwenl92@gmail.com \\ ${ }^{2}$ Fakultas Ilmu Komunikasi, Universitas Tarumanagara, Jakarta* \\ Email: diahc@fikom.untar.ac.id
}

Masuk tanggal : 15-12-2021, revisi tanggal : 06-01-2022, diterima untuk diterbitkan tanggal : 16-01-2022

\begin{abstract}
Technological developments are increasingly developing and increasingly sophisticated. Sending a message is made easier because of social media. Initially, social media was widely used as a means of sending messages quickly, but over time social media has also been used as a means for marketing and business within a company. In this study, researchers will examine the Burgushi Restaurant. Burgushi is a restaurant that serves food in the form of sushi combined with burgers. In this case, Burgushi uses Instagram media to advertise its products. Here the author wants to examine the effectiveness of Burgushi Product Ads through Instagram Ads on Millennial Generation Purchase Interest. This study aims to measure the effectiveness of advertisements through Instagram ads in attracting millennial buying interest. The theoretical basis used is marketing communication theory, advertising, advertising effectiveness, marketing, New Media, buying interest, and Millennial Generation. The approach in this research uses quantitative research. The method in this study uses a survey research method by distributing questionnaires to millennials. The sampling technique and population were purposive sampling. The sample used in this study were 100 respondents. The data collection method used was a questionnaire and used a Likert scale. The techniques used in data processing and analysis are editing, codeting, tabulation. The data validity technique used validity test, reliability test, normality test.
\end{abstract}

Keywords: advertising, buying interest, effectivness, marketing communications

\begin{abstract}
Abstrak
Kini mengirim sebuah pesan menjadi mudah karena adanya media sosial. Awalnya media sosial banyak dimanfaatkan sebagai sarana mengirim pesan dengan cepat, namun seiring berjalannya waktu sosial media juga dijadikan sarana untuk pemasaran dan bisnis dalam suatu perusahaan. Dalam penelitian ini peneliti akan meneliti Restoran Burgushi. Burgushi merupakan restoran yang menyajikan makanan berupa sushi yang di kombinasikan dengan burger. Dalam hal ini Burgushi menggunakan media Instagram dalam mengiklankan produknya. Disini penulis ingin meneliti efektivitas Iklan Produk Burgushi Melalui Instagram Ads Terhadap Minat Beli Generasi Milenial. Penelitian ini bertujuan untuk mengukur keefektivitasan iklan melalui Instagram ads dalam menarik minat beli kaum milenial. Landasan teori yang digunakan adalah teori komunikasi pemasaran, periklanan, efektivitas iklan, pemasaran, New Media, minat beli, dan Generasi Milenial. pendekatan dalam penelitian ini menggunakan penelitian kuantitatif. Metode pada penelitian ini menggunakan metode penelitian survei dengan cara menyebarkan angket kepada kaum milenial. Teknik pengambilan sample dan populasi adalah purposive sampling. Sample yang digunakan dalam penelitian ini sebanyak 100 responden. Metode pengumpulan data yang digunakan adalah kuesioner dan menggunakan skala likert. Teknik yang digunakan dalam pengolahan dan analisis data adalah editing, codeting, tabulasi. Teknik keabsahan data menggunakan uji validitas, uji reliabilitas, uji normalitas. Hasil penelitian menunjukkan adanya hubungan
\end{abstract}


yang erat antara efektivitas iklan melalui media Instagram terhadap minat beli generasi milenial.

Kata Kunci: efektivitas, komunikasi pemasaran, minat beli, periklanan

\section{Pendahuluan}

Pada zaman modern ini semuanya serba praktis dan mudah. Manusia dapat melakukan apa yang mereka inginkan hanya dengan media sosial seperti Line, Whatsapp, Tiktok, Instagram. Manusia dapat berkomunikasi dengan lancar dengan media sosial tersebut. Seiring berjalannya waktu, media sosial tidak hanya digunakan sebagai alat sarana komunikasi saja, kini media sosial dapat digunakan berbagai keperluan, seperti undangan pernikahan yang dapat dibagikan ke media sosial, ide berbisnis, sampai mengiklankan suatu produk.

Ketika belum mengenal media sosial, manusia berbisnis ataupun beriklan dengan menggunakan media radio, televisi, dan media. Namun kini iklan dapat diakses dengan menggunakan media sosial. Menurut Neti (Febrian dan Supriono, 2018), pemasaran media sosial merupakan upaya menggunakan media sosial yang bertujuan membujuk pembeli bahwa sebuah perusahaan, produk atau jasa sangat bermanfaat.

Dengan mengiklankan produk melalui media sosial, para pengusaha juga dimungkinkan untuk mendapatkan pelanggan yang banyak dikarenakan kini banyak orang yang menggunakan media sosial. Dengan begitu, semakin banyak pula orang yang terpapar iklan di media sosial. Mershon mengatakan, kegunaan media sosial pada suatu perusahaan yaitu sebagai berikut, sebagai sarana kontak personal dengan konsumen, menyampaikan respon ke konsumen dan sebagai dasar pengambilan keputusan bisnis (Pamungkas, 2019).

Iklan sendiri merupakan segala bentuk pesan promosi benda seperti barang, jasa, produk jadi, dan ide yang disampaikan melalui media dengan biaya sponsor dan ditujukan kepada sebagian besar masyarakat. Iklan didefinisikan sebagai pesan dalam merk, produk, atau perusahaan yang disampaikan kepada target pasar melalui media (Bennet dalam Aqsa, 2018). Salah satu platform media sosial yang kini banyak digunakan untuk beriklan adalah Instagram. Ini dikarenakan pengguna Instagram semakin meningkat jumlahnya dari waktu ke waktu. Instagram juga memiliki fitur Instastory. Fitur ini juga sering dimanfaatkan dalam mengiklankan suatu produk atau merek. Potensi inilah yang dilirik oleh Burgushi.

Dalam penelitiannya, Eryta (2013) mengatakan bahwa Instagram terlihat bertambah fungsi menjadi tempat strategis para pebisnis untuk memasarkan barang dagangannya. Produk jualan onlinenya mulai dari tas, sepatu, hingga baju fashion. Oleh sebab itu Instagram dari suatu merek harus semenarik mungkin. Dalam hal ini media Instagram yang dimiliki burgushi juga sudah cukup menarik dengan menggunakan nuansa berwarna kuning yang merupakan khas dari brand Burgushi.

Burgushi merupakan sebuah restoran yang memadukan burger Amerika dan sushi Jepang. Produk Burgushi dibuat untuk penggemar burger sekaligus penggemar sushi. Mereka yang gemar sushi sekaligus burger tidak perlu lagi membeli dua produk tersebut secara di dua tempat yang berbeda Mereka tinggal datang ke Burgushi dan dapat menikmati keduanya sekaligus.

Dari latar belakang di atas maka dapat dirumuskan permasalahan sebagai berikut Apakah iklan melalui media Instagram efektif untuk digunakan Produk Burgushi? Lalu Apakah media Instagram cukup untuk menarik minat beli generasi 
milenial? Sedangkan Tujuan dari penelitian ini adalah mengukur efektivitas iklan melalui media instagram terhadap brand Burgushi serta mengetahui ketertarikan minat beli masyarakat milenial dalam pembelian produk Burgushi.

\section{Metode Penelitian}

Metode penelitian yang digunakan dalam penelitian ini adalah metode penelitian kuantitatif. Pendekatan yang digunakan adalah pendekatan survei. Penelitian survei sering kali digunakan dalam ilmu sosial untuk membantu pengamatan terhadap suatu fenomena sosial. Dalam penelitian ini, penulis akan menyebarkan suatu kuesioner atau angket yang akan disebarkan di media sosial menggunakan google form yang berisikan pertanyaan-pertanyaan yang berhubungan dengan suatu objek penelitian. Peneliti juga akan membuat data statistik dari hasil yang telah didapat dari kuesioner yang telah diisi.

Populasi yang diteliti adalah generasi millenal yang mengetahui produk Burgushi dan pengikut Instagram Burgushi generasi milenial yang lahir antara 1980 hingga 2000 (Yuswohadi dalam Hidayatullah, et al., 2018). Teknik pengumpulan yang digunakan adalah purposive sampling.

\section{Hasil Temuan dan Diskusi}

Hasil penelitian secara menyeluruh menunjukkan adanya pengaruh antara Variabel Independen (Efektivitas Iklan), terhadap Variabel Dependen (Minat beli). Hal ini dapat dilihat dari Uji T, Pada tabel 4.29 menunjukan bahwa t 10, 838 sedangkan signifikasinya 0,000 maka dapat disimpulkan $0,000<0,05$ yang berarti variabel $\mathrm{X}$ berpengaruh pada variabel $\mathrm{Y}$ dimana $\mathrm{H} 1$ berbunyi adanya pengaruh yang signifikan antara efektivitas iklan melalui media Instagram terhadap minat beli generasi milenial. Artinya minat beli secara signifikan dipengaruhi dari efektivitas iklan melalui media Instagram.

Koefisien korelasi juga menunjukkan adanya hubungan yang erat antara efektivitas iklan melalui media Instagram terhadap minat beli generasi milenial, hal ini dapat ditunjukkan Dalam tabel $\mathrm{R}$ tersebut diketahui $\mathrm{R}$ yang didapatkan 0,738 hal ini berarti terdapat pengaruh yang besar diantara variabel $\mathrm{X}$ dan variabel $\mathrm{Y}$. Dari jawaban yang telah diberikan responden, juga merujuk bahwa minat beli generasi milenial juga dipengaruhi oleh efektivitas iklan di media Instagram. Responden juga menyetujui bahwa efektivitas iklan menggunakan media Instagram juga berpengaruh terhadap minat beli responden. Hasil dari beberapa Uji yang telah digunakan dalam penelitian ini adalah sebagai berikut

\section{Uji Validitas}

Berdasarkan hasil SPSS Versi 22 berikut hasil uji validitas terhadap variabel X dan Y dalam SPSS memiliki hukum $r$ hitung $>r$ tabel yang berarti data tersebut valid.

Tabel 1. Uji Validitas Variabel $X$

\begin{tabular}{llll}
\hline Variabel & R Hitung & R tabel & Keputusan \\
\hline & & & \\
\hline $\mathrm{X} 1$ & 0,375 & 0,165 & Valid \\
\hline $\mathrm{X} 2$ & 0,426 & 0,165 & Valid \\
\hline $\mathrm{X} 3$ & 0,589 & 0,165 & Valid \\
\hline
\end{tabular}




\begin{tabular}{llll}
\hline X4 & 0,782 & 0,165 & Valid \\
\hline X5 & 0,757 & 0,165 & Valid \\
\hline X6 & 0,746 & 0,165 & Valid \\
\hline X7 & 0,730 & 0,165 & Valid \\
\hline X8 & 0,538 & 0,165 & Valid \\
\hline
\end{tabular}

Sumber: Hasil Olah Data SPSS

Tabel 2. Uji Validitas Variabel Y

\begin{tabular}{llll}
\hline Variabel & R Hitung & R tabel & Keputusan \\
\hline Y1 & 0,644 & 0,165 & Valid \\
\hline Y2 & 0,567 & 0,165 & Valid \\
\hline Y3 & 0,623 & 0,165 & Valid \\
\hline Y4 & 0,693 & 0,165 & Valid \\
\hline Y5 & 0,650 & 0,165 & Valid \\
\hline Y6 & 0,684 & 0,165 & Valid \\
\hline Y7 & 0,670 & 0,165 & Valid \\
\hline Y8 & 0,630 & 0,165 & Valid \\
\hline Y9 & 0,630 & 0,165 & Valid \\
\hline Y10 & 0,647 & 0,165 & Valid \\
\hline Y11 & 0,630 & 0,165 & Valid \\
\hline Y12 & 0,647 & 0,165 & Valid \\
\hline Sumb
\end{tabular}

Sumber: Hasil Olah Data SPSS

\section{Uji Reliabilitas}

Dari hasil SPSS 22 variabel X dan Variabel Y dinyatakan konsisten apabila alpha > $r$ tabel oleh sebab itu hasil dari penelitian melalui spss versi 22 adalah sebagai berikut

Tabel 3. Uji Reliabilitas Variabel X

\begin{tabular}{c}
\hline \multicolumn{2}{c}{$\begin{array}{c}\text { Cronbach's } \\
\text { Alpha }\end{array}$} \\
\hline Sumber: Hasil Olah Data SPSS
\end{tabular}

Alpha yang didapat dari Variabel $\mathrm{X}$ adalah 0,658 dan $\mathrm{r}$ tabel nya 0,165 yang berarti $r$ tabelnya lebih kecil daripada alpha. Maka dari itu reliabilitas variabel X adalah konsisten

Tabel 4. Uji Reliabilitas Variabel Y

\begin{tabular}{rr}
\hline $\begin{array}{c}\text { Cronbach's } \\
\text { Alpha }\end{array}$ & N of Items \\
\hline, 863 & 12 \\
\hline
\end{tabular}

Sumber: Hasil Olah Data SPSS

Alpha yang didapat dari Variabel Y adalah 0,863 dan $r$ tabel nya 0,165 yang berarti $r$ tabelnya lebih kecil daripada alpha. Maka dari itu reliabilitas variabel Y adalah konsisten 


\section{Uji Normalitas}

Tabel 5. Uji Normalitas

\begin{tabular}{llr}
\hline & & Unstandardized Residual \\
\hline Normal Parameters & & 100 \\
\hline Most Extreme Differences & Mean &, 0000000 \\
\cline { 2 - 3 } & Std. Deviation & 4,78460632 \\
\cline { 2 - 3 } & Absolute &, 082 \\
\cline { 2 - 3 } & Positive &, 049 \\
\cline { 2 - 3 } & Negative &,- 082 \\
\hline Test Statistic & &, 082 \\
\hline Asymp. Sig. (2-tailed) & &, $097^{\mathrm{c}}$ \\
\hline a. Test distribution is Normal. & \\
b. Calculated from data. & & \\
c. Lilliefors Significance Correction. & & \\
Sumber: Hasil Olah Data SPSS & &
\end{tabular}

Uji Signifikasi Pengaruh Parsial (Uji T)

\begin{tabular}{|c|c|c|c|c|c|c|}
\hline \multirow{2}{*}{\multicolumn{2}{|c|}{ Model }} & \multicolumn{2}{|c|}{ Unstandardized Coefficients } & \multirow{2}{*}{$\begin{array}{c}\begin{array}{l}\text { Standardized } \\
\text { Coefficients }\end{array} \\
\text { Beta } \\
\end{array}$} & \multirow[b]{2}{*}{$\mathrm{t}$} & \multirow[b]{2}{*}{ Sig. } \\
\hline & & $\mathrm{B}$ & Std. Error & & & \\
\hline \multirow[t]{2}{*}{1} & (Constant) & 8,414 & 3,835 & & 2,194 &, 031 \\
\hline & $\begin{array}{l}\text { Efektivitas } \\
\text { Iklan }\end{array}$ & 1,653 & , 153 & ,738 & 10,838 &, 000 \\
\hline
\end{tabular}

a. Dependent Variable: Minat Beli

Sumber: Hasil Olah Data SPS

Ketentuan Uji T adalah sebagai berikut Jika nilai Sig. $<0,05$ maka variabel bebas berpengaruh signifikan terhadap variabel terikat. Sedangkan jika nilai Sig. > 0,05 maka variabel bebas tidak berpengaruh signifikan terhadap variabel terikat. Pada tabel diatas menunjukan bahwa t 10,838 sedangkan signifikasinya 0,000 maka dapat disimpulkan $0,000<0,05$ yang berarti variabel $\mathrm{X}$ berpengaruh pada variabel $\mathrm{Y}$.

\section{Hasil Koefisien Korelasi}

Tabel 7. Koefisien Korelasi

\begin{tabular}{l|r|r|r|r}
\hline Model & R & R Square & $\begin{array}{c}\text { Adjusted R } \\
\text { Square }\end{array}$ & $\begin{array}{c}\text { Std. Error of } \\
\text { the Estimate }\end{array}$ \\
\hline 1 &, $738^{\mathrm{a}}$ &, 545 &, 541 & 4,80896 \\
\hline
\end{tabular}

Dalam tabel tersebut diketahui $\mathrm{R}$ yang didapatkan 0,738 hal ini berarti terdapat pengaruh yang besar diantara variabel $\mathrm{X}$ dan variabel $\mathrm{Y}$. 


\section{Analisis Regresi Linier Sederhana}

Tabel 8. Regresi Linear Sederhana

\begin{tabular}{|c|c|c|c|c|c|c|}
\hline \multicolumn{7}{|c|}{ Coefficients $^{\mathrm{a}}$} \\
\hline \multirow[b]{3}{*}{ Model } & & \multirow{2}{*}{\multicolumn{2}{|c|}{ Unstandardized Coefficients }} & Standardized & \multirow[b]{3}{*}{$\mathrm{t}$} & \multirow[b]{3}{*}{ Sig. } \\
\hline & & & & Coefficients & & \\
\hline & & B & Std. Error & Beta & & \\
\hline 1 & (Constant) & 8,414 & 3,835 & & 2,194 &, 031 \\
\hline & Efektivitas Iklan & 1,653 &, 153 & ,738 & 10,838 & 000 \\
\hline
\end{tabular}

a. Dependent Variable: Minat Beli

Sumber: Hasil Olah Data SPSS

Rumus dari Analisis Regresi Linear Sederhana adalah sebagai berikut $\mathrm{Y}=\mathrm{a}+$ bX dimana dalam tabel 4.31 diketahui a nya adalah 8,414 sedangkan b 1,653 berarti jika dimasukan Rumus adalah sebagai berikut $\mathrm{Y}=8,414+1,653 \mathrm{X}$.

\section{Simpulan}

Setelah melakukan penelitian mengenai efektivitas iklan Burgushi melalui Instagram Ads, dapat disimpulkan bahwa Menurut Yustisia (2018) Efektivitas Iklan dibagi menjadi 2 dimensi yaitu Efektivitas Komunikasi dan Efektivitas Pemasaran. Efektivitas Komunikasi meliputi keterbukaan, sikap empati, sikap mendukung dan kesetaraan, sedangkan Efektivitas pemasaran meliputi empati, perhatian, impact, dan komunikasi. Bila dilihat dari dimensi tersebut dimensi yang paling berpengaruh adalah dimensi Efektivitas Pemasaran yang meliputu sikap empati, perhatian, impact, dan komunikasi.

Dalam Penelitian ini hasil penelitian secara menyeluruh menunjukkan, adanya pengaruh antara Variabel Independen (Efektivitas Iklan), terhadap Variabel Dependen (Minat beli). Hal ini dapat dilihat dari Uji T, Pada tabel 4.29 menunjukan bahwa t 10 , 838 sedangkan signifikasinya 0,000 maka dapat disimpulkan $0,000<0,05$ yang berarti variabel $\mathrm{X}$ berpengaruh pada variabel $\mathrm{Y}$ dimana $\mathrm{H} 1$ berbunyi adanya pengaruh yang signifikan antara efektivitas iklan melalui media Instagram terhadap minat beli generasi milenial.

Koefisien korelasi juga menunjukkan adanya hubungan yang erat antara efektivitas iklan melalui media Instagram terhadap minat beli generasi milenial, hal ini dapat ditunjukkan Dalam tabel 4.30 tersebut diketahui $\mathrm{R}$ yang didapatkan 0,738 hal ini berarti terdapat pengaruh yang besar diantara variabel $\mathrm{X}$ dan variabel $\mathrm{Y}$.

\section{Ucapan Terima Kasih}

Peneliti ingin mengucapkan terima kasih kepada Fakultas Ilmu Komunikasi Universitas Tarumanagara, narasumber, serta semua pihak yang turut membantu peneliti sehingga penelitian ini dapat diselesaikan.

\section{Daftar Pustaka}

Aqsa, Muhammad. (2018). Pengaruh Iklan Online Terhadap Sikap dan Minat Beli Konsumen Secara Online di Kota Palopo (Survei Pada Pengguna Internet di Kota Palopo). Prosiding Seminar Nasional Vol. 3(1). 
Eryta. (2013). Aplikasi Instagram Sebagai Media Komunikasi Pemasaran Online Shop. Skripsi, Universitas Pembangunan Nasional "Veteran" Jawa.

Febrian dan Supriono. (2018). Pengaruh Pemasaran Media Sosial Terhadap Brand Awareness Pada Produk Internasional (Survei Pada Komunitas Xiaomi Indonesia). Jurnal Administrasi Bisnis, Vol. 61(1).

Hidayatullah, S., et al. (2018). Perilaku Generasi Milenial dalam Menggunakan Aplikasi Go- Food. Jurnal Manajemen dan Kewirausahaan Vol 6(2).

Pamungkas, Imanuel Panji. (2019). Pemanfaatan Media Sosial Instagram Sebagai Media Periklanan UMKM Di Beteng Trade Center (BTC) Solo. Jurnal Universitas Sebelas Maret. 